\title{
How can business buyers attract sellers' resources?
}

\section{Empirical evidence for preferred customer treatment from suppliers.}

Roger Baxter, Auckland University of Technology

October 2012

Send correspondence to:

Roger Baxter

Faculty of Business, Auckland University of Technology, Private Bag 92006, Auckland 1142,

New Zealand

Telephone: +64 99219999

Fax: +64 99219269

Email: roger.baxter@aut.ac.nz 


\section{Biographical Sketch of Author}

Roger Baxter is Senior Lecturer at the Auckland University of Technology, New Zealand, where he researches business relationships and teaches marketing. He has published in journals that include Industrial Marketing Management and the Journal of Business Research.

\section{Acknowledgements}

The author gratefully acknowledges several contributions to this paper. The Auckland University of Technology funded the data collection for the study and the author's colleagues at the university, including Associate Professor Sonjaya Gaur and Associate Professor Ken Hyde, provided much useful input to development of the paper. The special issue editor and the anonymous reviewers were particularly helpful in development of the manuscript. 


\section{Research highlights}

- This study investigates what makes a business buyer attractive to a seller

- Increased attractiveness encourages sellers’ preferential treatment to customers

- Supplier satisfaction and commitment facilitate the preferred treatment 


\title{
How can business buyers attract sellers' resources?
}

\section{Empirical evidence for preferred customer treatment from suppliers}

\begin{abstract}
This paper describes a study that investigates what makes a buyer attractive to a seller in a business-to-business buyer-seller relationship and encourages the seller to commit to and invest resources preferentially in the relationship. The study helps answer the question, "What is it that the buyer needs to do to create this attractiveness?” The perspective is somewhat unusual in the marketing literature for two reasons. Firstly, because it investigates how the supplier perspective of customer financial attractiveness affects the attitudes and actions of the supplier towards the buyer, rather than taking the buyer's perspective across the relationship. Secondly, the study has relationship attractiveness in terms of financial performance as an antecedent of its relationship constructs, whereas most relationship studies investigate performance as an outcome. The paper develops a model that proposes the seller's perception of customer financial attractiveness, seller satisfaction, and seller commitment as drivers of the seller's preferred customer treatment by allocation of resources to the relationship. The bases for the study's model are the resource-based view of the firm, the industrial marketing and purchasing (IMP) models, and related resourcefocused theoretical streams. The study finds support for the model in the analysis of survey data.
\end{abstract}

\section{Key words}

Customer financial attractiveness; preferred customer treatment; relationship; resource investment; supplier commitment; supplier satisfaction 


\section{How can business buyers attract sellers' resources?}

\section{Empirical evidence for preferred customer treatment from suppliers}

\section{Introduction}

The Industrial Marketing Management “reverse perspective” special issue calls for papers that address one of the less-researched perspectives of partner value and hence partner attractiveness in a relationship. This featured perspective is the attractiveness of the buyer to the seller, rather than of the seller to the buyer, and is the subject of this paper. This paper adds to knowledge of this perspective by describing a study that investigates the following key points. Firstly, the study tests that a buyer can gain preferred customer treatment, in terms of attracting resource inputs from a seller, by way of ensuring good financial performance of the relationship and secondly, the study quantitatively verifies, from suppliers' perspective, that suppliers differentiate the service they offer to customers. Thirdly, the study tests two facilitating constructs, supplier satisfaction and supplier commitment, for their effects on the level of preference a supplier gives to a more attractive customer by way of its resource inputs into the relationship. The study further establishes that supplier commitment to a relationship and the preference given to attractive high-performing customers are two distinct relationship effects. The paper thus helps to establish what a buyer needs to do to improve its attractiveness to a supplier and what will encourage the supplier to commit to and preferentially invest resources in the relationship. Fourth, the study provides empirical evidence for the theoretical streams on which it is grounded. 
The paper's perspective is somewhat unusual in the marketing literature for two reasons. Firstly, because it investigates how supplier perceptions of customer attractiveness in terms of financial performance affect the attitudes and actions of the supplier towards the buyer rather than taking the buyer's perspective across the relationship. Secondly, the study has relationship performance as an antecedent of a set of relationship constructs, whereas many relationship studies investigate performance as an outcome.

There are four possible perspectives of partner attractiveness in a relationship. They comprise on the one hand the value of the buyer to the seller as seen by each of the buyer and the seller and on the other hand the value of the seller to the buyer as seen by each of the buyer and the seller. The value of the seller and/or its offerings to the buyer is a commonly researched topic and is the one that has in the past come to mind most readily for marketing practitioners and researchers, for good reason: the value of the seller and its offering is what determines how much the buyer purchases. However, as buyer-seller collaborations in the co-creation of value come to the fore in management and research thinking, particularly since interest in the service-dominant logic (S-DL) of marketing (Vargo \& Lusch, 2004) increases, the value of the buyer to the seller in the perspective of each of the two relationship partners increasingly becomes a focus for managers and researchers. There is good reason for this, as the S-DL helps explain: all firms need resources and many of these resources come from outside the firm, including from partners in buyer-seller relationships.

The rationale for the study is that the attitude and actions of the supplier, particularly with respect to the supplier's commitment and its consequent allocation of resources, is an issue of considerable concern to the buyer, which needs to know how best to make itself an attractive business partner for a supplier. The buyer wants not only the supplier’s product offering: it also 
wants resources such as information about the supplier's product, its product application, how to process the supplier's product, the supplier's IT and logistics services, and especially the supplier's information that will help the buyer create value in the relationship and in its other relationships such as with its own customers.

Although the need for buyers to encourage supplier commitment is a topic that researchers have investigated in the supply chain and logistics literature, marketing-oriented researchers have not looked at this topic in depth until fairly recently. Schiele and co-authors (Schiele, 2012; Schiele \& Krummaker, 2011; Schiele, Veldman, \& Hüttinger, 2011) recently study the positive effect that being a supplier's preferred customer can have on that customer's level of innovation. The customer's position as a preferred customer motivates the supplier to assist with innovation as Schiele, Veldman, \& Hüttinger (2011) hypothesize and support empirically. Although IMP (Industrial Marketing and Purchasing) group researchers (Hakansson \& Snehota, 1982; Håkansson \& Snehota, 1995) have studied the effect of relationship atmosphere on resource allocation by suppliers for some years, there is little quantitative work in the marketing research literature that has outcomes of supplier commitment and preferred customer treatment as the result of greater customer attractiveness. Research into this topic appears to be important, because it will help buyers to understand how they should act in order to preferentially attract suppliers' resources. This study therefore helps to round out the research into this aspect of buyer-seller relationships by quantitatively assessing these outcomes in a model described and tested below.

Although the "reverse perspective" of creation of positive relationship outcomes has featured less frequently in marketing research, there are some existing studies that provide precedents. For example, some studies of relationship value take this perspective. Baxter and 
Matear (2004) identify a set of outcome dimensions of the intangible aspects of the value of a business-to-business buyer to its supplier. The Baxter and Matear study is from the supplier's perspective, using an approach based on the intellectual capital literature. Walter and Ritter (2001) also take the perspective of the seller in identifying a set of drivers of value in a businessto-business buyer-seller relationship. Both these studies have recognized the importance to sellers of buyers who can give them resources that lead to creation of value.

However, many questions remain unanswered with respect to attractiveness and value assessment in business-to-business buyer-seller relationships. This is particularly true from a seller's perspective of a buyer's desirability and attractiveness, and their antecedents. The attractiveness of a buyer affects the seller's attitude and actions towards the buyer and consequently affects how much resource the seller is willing to provide the buyer through the relationship. Buyers need to get resources from their suppliers. An issue that is therefore of specific relevance to a buyer, in these times where there is competition by buyers for the "best" suppliers, is how to develop and retain the supplier commitment so buyers can get these resources. The subjects of the investigation described in this paper are therefore the attractiveness of the customer to a seller in terms of financial performance of the relationship, the supplier's satisfaction with a buyer-relationship, supplier commitment to a buyer, and the supplier's preferred customer treatment by way of preferential input of resources to the relationship as an outcome of supplier commitment.

This paper now establishes a conceptual basis for the study it describes and proposes a model incorporating the constructs above as antecedents, mediators and outcomes. The paper then describes the empirical testing of the model and discusses the results of the empirical work with their implications for management and for future research. 


\section{Conceptual development}

As Palmatier, Dant \& Grewal (2007) point out, researchers consider relationships from many different theoretical perspectives. The theoretical perspective taken in this study derives from the resource-based view (RBV) of the firm, seen as a particularly useful one by Palmatier et al. (2007) for describing and analyzing relationships, combined with some of the concepts of the IMP group and the S-DL of marketing (Vargo \& Lusch, 2004). A common provenance links these theoretical streams in the work of Penrose (1959), in which she describes the firm and its resources.

That theoretical grounding provides the rationale for the model shown in Figure 1 below. The model proposes that the supplier's higher perception of the future financial performance of the relationship with the customer leads to greater customer attractiveness and hence to greater levels of preferred customer treatment by the supplier both directly and through supplier satisfaction and supplier commitment as mediators. The overarching logic for the model comes from the notion in all three of the theoretical streams noted above that resource exchange ("service exchange” in the S-DL) and hence resource availability from a partner is fundamental to value creation. Reciprocity of exchange is a strong element of the three theory streams, especially the S-DL (see, e.g. Vargo, 2009, page 374) and the IMP’s interaction approach to relationships (Hakansson \& Snehota, 1982). This reciprocity view supports the proposal of the model that the seller's perception of high performance of the customer relationship, which is important to the seller's perception of the customer's attractiveness, leads to the supplier's higher level of satisfaction and commitment and hence to the seller's higher level of input of resources 
for this relationship, in other words leads to the seller treating that customer as a preferred customer.

Figure 1 about here.

Researchers in marketing and other disciplines have extensively investigated commitment and constructs such as satisfaction that are closely related nomologically, over the last twenty years or so (e.g. Palmatier, Dant, Grewal, \& Evans, 2006; Ulaga \& Eggert, 2006). There are many possible perspectives of these constructs that managers must take into consideration and which researchers can take for their investigations. For example, a buyer considers both its commitment to a supplier and its own view of the commitment of the supplier to the relationship when taking strategic or tactical actions. From the other side of the relationship, a seller similarly considers both its commitment to a customer and its own view of the commitment of the customer. A firm's commitment to the relationship with its partner closely relates to the effort it puts into that relationship.

Much of the satisfaction and commitment research described in the marketing literature to date has been into the commitment by a buyer to a seller or satisfaction of a buyer with a seller. The perspective is often that of the buyer, as exemplified by Morgan and Hunt's (1994) seminal paper on commitment and trust, conceptualized as mediators between other relationship constructs. The preponderance of this perspective is probably due to the view that marketing's job is to "sell things", taking into account the view of relationship marketing that in order to be successful in doing so, the seller must gain the commitment and satisfaction of the buyer to the 
relationship. This unidirectional view of marketing functions is quickly changing as managers realize the importance of the resources possessed by their customers.

As a consequence of this changing view, there is considerable interest in the broader research literature in supplier commitment to customers and in supplier satisfaction. Researchers study how the customer can engender this supplier commitment and satisfaction, particularly in the logistics and purchasing literature. As Handfield, Krause, Scannell, \& Monczka (2000) point out, “a buyer’s team must clearly delineate potential rewards for the supplier organization” in order to gain supplier commitment. The level of interest in increasing the attractiveness of a buyer to sellers seems to increase as focus intensifies on the need to develop co-creative opportunities through relationships and on the benefit that buyers can realize from high levels of resource input and supplier commitment. Several studies of supplier input to new product development and its benefits (e.g. Petersen, Handfield, \& Ragatz, 2005; Ragatz, Handfield, \& Petersen, 2002) and management (Schiele, 2010; Van Echtelt, Wynstra, Van Weele, \& Duysters, 2008) are available, so the importance to buyers of the resources that sellers can bring is well established. Buyers need to attract sellers and need to understand what they can do to attract sellers. This study aims to add to knowledge of what it is that buyers need to do in order to attract sellers by developing a model of the important factors in this process.

The following sections describe the constructs in the proposed model and the paths between them in more depth. The perspective that the study takes is this. Firstly, the study is of business-to-business buyer-seller relationships. The aim is to help illustrate in that context what buyers need to do in order to attract suppliers and gain supplier satisfaction and commitment, and what is an important driver of these attitudes and thus a driver of sellers' allocation of resources to the buyer. The study therefore shows what will encourage sellers in their attitudes and in their 
preferred customer treatment. The buyer needs to understand this from the seller's perspective, so the constructs all take the perspective of the seller towards the relationship with the buyer.

The customer financial attractiveness construct in Figure 1 is therefore the financial performance of the relationship with this customer as judged by the supplier. Commitment and satisfaction are the supplier's commitment to and satisfaction with the buyer. The preferred customer treatment construct represents the intentions the supplier has to preferentially put resources into the relationship with the buyer in future. The study aims to clarify how the buyer might best deal with the supplier in order to get supplier commitment and preferred treatment in other words, how the buyer might “compete” for the supplier’s attention. Commitment and preferred treatment are what the buyer wants from the supplier, so they are key constructs in the model. Supplier perceptions of future relationship performance, supplier satisfaction, and supplier commitment are what the buyer needs to encourage positively so it can achieve its desired outcomes in terms of a high level of preferred treatment by the seller. These latter constructs are important in relationship management, as Palmatier et al. (2006) point out. Although the Palmatier et al. perspective is different, and they investigate the relationships between those constructs from the perspective of the buyer's belief about the seller, not the seller's belief about the buyer, their findings nonetheless support this study in applying to relationships in general. The following sections of the paper describe the Figure 1 model, commencing with customer financial attractiveness and seller's preferred customer treatment and then working through the mediating constructs and the paths that join the constructs.

\subsection{Customer attractiveness and preferred customer treatment}


Members of the IMP group (Hakansson \& Snehota, 1982; Håkansson \& Snehota, 1995) have studied the exchange of resources through buyer-seller relationships for many years in terms of the IMP's actors, resources and activities (ARA) model, and its researchers have made the importance of resource exchange very clear in business-to-business contexts (e.g. Anderson, Håkansson, \& Johanson, 1994; Gadde, Huemer, \& Håkansson, 2003). Exchange and integration of resources, both tangible and knowledge-based resources (Baraldi \& Waluszewski, 2007), is essential to relationship functioning and specifically to value co-creation and hence to attractiveness of the relationship. Each party in the relationship has information that will benefit their joint success. The buyer might have downstream market information for example, which can aid the seller in providing better products and processes to the buyer and the seller might have design knowledge that will be useful to the buyer.

Now that managers and researchers of buyer-seller relationships see each partner in a buyer-seller relationship as an important source of resources and hence of co-creation of value (Ballantyne \& Varey, 2006; Payne, Storbacka, \& Frow, 2008), interest increases in the ability and willingness of a partner to provide resources and hence their level of resource provision is a judgment criterion for partners. Because buyers need resource inputs from sellers, the focal points of this paper are the level of preferred customer treatment by the seller in the form of these resource inputs into the relationship, the supplier's satisfaction and commitment that influence it, and the seller's perception of the customer's attractiveness in the form of expected future financial performance of the relationship with that customer. The paper now describes the first and last constructs in Figure 1 and the relationship between them. The paper will then describe the two mediating constructs, supplier commitment and supplier satisfaction, and the other relationships in the figure. 
The construct on the left of Figure 1 is customer financial attractiveness, in the perceptions of the seller. This study specifies customer attractiveness as financial performance. The financial specification is used because, although there are good arguments to include both financial and non-financial benefits as indicators of performance (O'Toole \& Donaldson, 2000) in the shorter term, in the long term non-financial benefits become of value only when they realize their value financially. Financial measures thus comprehensively assess relationship performance.

This study conceptualizes relationship performance as an antecedent of other relationship constructs in Figure 1, which is perhaps unusual. There are some studies of relationship performance as an outcome of other marketing constructs using profitability as the measure (e.g. Wiley, Wilkinson, \& Young, 2005) or using broader measures (e.g. O'Toole \& Donaldson, 2002), but few if any specific studies of relationship performance in the literature as an antecedent of other constructs. This is despite the fact that it is very likely that relationship performance has an effect on the actions of relationship partners.

In particular, relationship performance is antecedent to preferred customer treatment by the supplier in this study, which is at the right of Figure 1. This preferred customer treatment is a construct that describes the relative intended level of resource allocation by the supplier, compared to its allocations to other customers, as is clear in the wording of the relevant questionnaire stem in the appendix. Respondents to the survey report on the level of allocation of a set of typical resources, by their firm, to the customer that is the subject of the questionnaire.

Despite the apparently unusual position of relationship performance in this study, there is in fact precedent for this positioning. A Palmatier et al. (2006) meta-analysis of relationship marketing publications finds that a broader construct, relationship benefits, does appear in the 
literature as a mediated antecedent of other relationship constructs, for example in Morgan and Hunt's (1994) study. This finding supports the proposition that future relationship performance is an antecedent to other relationship constructs, because relationship performance is clearly a relationship benefit for the seller as specified in this study. Palmatier et al. also find, in their meta-analysis, good evidence that relationship benefits antecede “cooperation”, which goes by other names such as “coordination” and “joint actions” as an outcome of relationship benefits, mediated by relationship quality constructs such as supplier commitment and satisfaction. The preferred customer treatment construct is an expression of the future level of cooperation with the buyer intended by the supplier in this study, so the Palmatier et al. finding supports the structure of the model in Figure 1.

The above review thus leads to the following direct-path hypothesis in Figure 1:

H1: the higher the customer financial attractiveness, the higher the level of preferred customer treatment.

\subsection{Supplier commitment}

The Figure 1 model shows supplier commitment as an important antecedent to preferred customer treatment in the form of resource allocation by suppliers and as a mediator of the path from customer financial attractiveness. There are close links between supplier commitment and supplier allocation of resources in the literature (e.g. Bennett \& Gabriel, 2001; Joshi, 2009) so this section elaborates these links and the mediation effect, but the study conceptualizes them as distinct constructs. It is possible for an organization to be committed to all its customers in the sense of seeing them as long-term partners, which is how supplier commitment is defined for this 
study, but at the same time to recognize that some customers are more attractive than others and hence to provide preferred customer treatment to those by providing them with more resources. Commitment, whether seen from a more affective sociological viewpoint (e.g. Morgan \& Hunt, 1994) or a more calculative switching-cost or transaction-cost viewpoint (e.g. Geyskens, Steenkamp, Scheer, \& Kumar, 1996), is central to the conduct of relationships. Commitment is an important marker of stages in the development of a relationship (Ford, 1980). Although there are exceptions (Jap \& Ganesan, 2000; Walter, 2003), the marketing literature is principally concerned with commitment of a buyer to a supplier rather than of supplier commitment to a buyer. In contrast, there are plenty of examples of studies of supplier commitment in other fields such as management (Provan \& Gassenheimer, 1994), operations (Prahinski \& Benton, 2004), and purchasing and supply management (Ghijsen, Semeijn, \& Ernstson, 2010). The concept of supplier commitment is therefore well established.

The focal conception of inter-firm relationship commitment is that a firm intends to maintain the relationship. This study uses the commitment conceptualization of Morgan and Hunt (1994) and uses some of their indicators, modified as commitment of the supplier to the buyer rather than of the buyer to the supplier as in Morgan and Hunt's study.

There is clear evidence in the literature for a link between supplier commitment and resource inputs by a partner, from multiple relationship perspectives. Krause (1999) tests a hypothesis that is very relevant to this study despite its taking the perspective of the buyer firm resource inputs rather than the perspective that this paper describes. Krause's hypothesis is that the buying firm will engage in supplier development if they believe that the supplier is committed to the relationship with them. Supplier development in Krause's study is “any effort of a buying firm with a supplier to improve the supplier's performance and/or capabilities”, and 
the questionnaire items are clearly indicators of buyer input of resources, such as

“Training/education of the supplier’s personnel”. Krause’s empirical test of this hypothesis gave it strong support.

With a different perspective from Krause (1999) and a similar perspective to this paper, a study of business-to-business manufacturer relationships empirically supports supplier involvement in customer new product development as an outcome of supplier commitment (Walter, 2003). Walter's study interprets supplier involvement as the allocation of resources to the customer for new product development by the supplier, analogous to the current study's preferred customer treatment construct. These resource allocations are in forms such as idea generation and prototype building.

Based on the literature noted above, this study tests the following hypotheses, illustrated in Figure 1, as expressions of the mediating role of supplier commitment:

H2: the higher the supplier commitment, the higher the level of preferred customer treatment.

H3: the higher the customer financial attractiveness, the higher the supplier commitment.

\subsection{Supplier satisfaction}

Satisfaction also appears widely in the marketing literature as a relationship mediator. Similarly to commitment, researchers study satisfaction from the supplier perspective more in other disciplines than in marketing, for example in quality management studies (e.g. Wong, 2000; Wong, 2002), where it appears to have a mediating role, and in purchasing and supply 
management (e.g. Essig \& Amann, 2009). However, supplier satisfaction is very much in the buyer's interest, because when suppliers are satisfied they will find buyers attractive propositions as business partners. Suppliers will then be encouraged to allocate more resources to their more attractive customers. This study includes satisfaction because other studies find that it is such an important mediating variable in relationships as noted above (Palmatier et al., 2006). For example, Ulaga and Eggert (2006) find satisfaction is a mediator between relationship value and relationship outcomes. The study expresses the Figure 1 mediating function of supplier satisfaction in the following two hypotheses:

H4: the higher the supplier satisfaction, the higher the preferred customer treatment.

H5: the higher the customer financial attractiveness, the higher the supplier satisfaction.

"Satisfaction is a function of performance to date” (Gustafsson, Johnson, \& Roos, 2005) and leads to commitment. Satisfaction therefore logically fits as a mediator between supplier perception of customer attractiveness, in terms of financial performance, and supplier commitment. Thus there is reason to hypothesize a path from supplier satisfaction to supplier commitment as well as to suppliers' preferred customer treatment on the basis that this path frequently finds support in prior relationship studies (Abdul-Muhmin, 2005; Geyskens, Steenkamp, \& Kumar, 1999; Ulaga \& Eggert, 2006). Hence, the study tests a sixth hypothesis:

$H_{6}$ : the higher the supplier satisfaction, the higher the supplier commitment. 


\subsection{Potential moderator variables}

The study investigates eight variables as potential moderators of the model's paths. The rationale for all these variables is that they are established in the marketing literature as covariates of relationship constructs of the type assessed in this study as focal constructs. The individual rationale for each of these potential moderators follows.

Firm sizes. As Ritter and Walter (2012) note, firm size may have an influence on availability of resources allocation, on relationship processes and on relative power of relationship parties, so there is the possibility that size could affect the model's relationships. The study therefore assesses the size of both buyer and seller, in terms of employee numbers, as moderators.

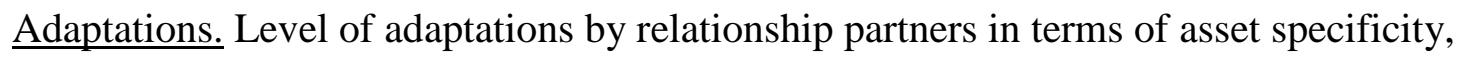
both physical (Walter, 2003) and human (Dyer, 1996), often show a clear effect on perceptions of relationship value constructs (Fang, Palmatier, \& Evans, 2008) and performance, so the level of adaptations by both buyer and seller are included as moderators in this study.

Service versus product in offering. There is an argument that the level of service versus product in a supplier's offering can affect associations between relationship constructs, although Palmatier (2008) found no significant effect in his study. This study tests service versus product as a moderator, the measure for which is in the appendix.

Trust. Similarly to Ritter \& Walter (2012), trust is conceptualized outside this study’s main model, in this case as a moderator rather than a focal construct, because of the calculative nature of both the customer financial attractiveness antecedent and the preferred customer treatment outcome, which is specified in terms of resource inputs. Williamson (1993, page 463) argues convincingly from an economic perspective that "Calculative trust is a contradiction in 
terms”, although a more calculative assessment of trust than that of Morgan \& Hunt (1994) has been researched in marketing (e.g. Suh \& Kwon, 2006).

Mutual goals and level of social bonds. The study also tests two other relationship constructs, mutual goals and level of social bonds, as moderators. Wilson (1995) notes these two relationship constructs as important ones that affect relationship outcomes. Mutual goals “provide a strong reason for relationship continuance” and hence are likely to be related to the paths leading to commitment in Figure 1, as do social bonds (Berry, 1995; Hennig-Thurau, Gwinner, \& Gremler, 2002).

\section{Testing the proposed model}

\subsection{Method}

The first empirical stage of the study comprised a set of interviews with eight managers as an initial assessment of the validity of the constructs and their indicators. The managers interviewed were relevant to the study in that they were all closely involved in relationships with their firm's customers, ascertained by the researcher prior to the interview. Their titles ranged from Product Manager to General Manager, the latter having a sales background and being closely involved with major customers. The study then pre-tested a draft questionnaire in interviews with relevant researchers and managers and made minor consequent modifications to the questionnaire. A pilot mail-out to members of the sample frame again resulted in minor modifications; the main modification was to ask respondents to choose their fourth largest customer as the questionnaire subject rather than allowing them to make their own choice, as the pilot showed they otherwise tended to skew to "good" customer relationships. This procedure for 
choice of questionnaire subject follows that of Anderson and Narus (1990) and was first assessed for suitability by asking nine sales managers to assess how good a customer was their fourthlargest. These sales managers were able to immediately identify their fourth-largest in a telephone conversation and reported a spread of relationship types, which suggested the procedure would help improve the level of variance and this turned out to be true. The main mail-out surveyed managers in sales- and marketing-responsible positions who were involved in relationship management. Their positions were mainly as sales managers (44.6\%), marketing managers (21.0 \%), sales and marketing managers (13.7\%) or in a CEO/General Manager/Director position (8.6 \%). Numbers of employees in the respondent's firm ranged in bands from 5 to 9 up to 1,000 or over, with the highest proportion, at 32\%, in the 20 to 49 employees range. Numbers of employees in the firm the respondent used as the questionnaire subject likewise ranged in bands from 5 to 9 up to 1,000 or over, with the highest proportion, at $21 \%$, in the 1,000 or more employees range. Respondents’ firms represented a wide range of industry types. Some of the larger representations were in food and tobacco (20 responses), printing and publishing (26), pulp, paper, board making machinery and printing and office machinery (24).

The English-language survey collected data in a single-wave mail-out with a postcard reminder, on 7 point scales with anchor points such as "strongly disagree” to "strongly agree”. The questionnaire design incorporated many of Dillman's (1978) suggestions. The unit of analysis was a relationship that the responding supplier had with a specific customer, as can be seen from the question formulation in the appendix. The number of responses to the survey, after excluding four incomplete questionnaires, was 314, representing a $23 \%$ response rate based on a mail-out of 1407 questionnaires to a random selection of manufacturers in the Kompass New 
Zealand database. Comparison with $t$-tests on the early and late responses to indicators of the constructs in the model did not indicate non-response bias (Armstrong \& Overton, 1977).

The study asks a single informant to respond to survey items, so there is the possibility of common method bias. The questionnaire design attempts to reduce this bias, based on the literature (e.g. Podsakoff, MacKenzie, Lee, \& Podsakoff, 2003), without compromising other needs such as logical question order. The anchor points for the intervening variables are different from one another and from the anchors for the antecedent and outcome variables. The stems and instructions for all constructs are different and the wording style of items varies across constructs in most cases. Analysis of the data suggests that common method bias is not a problem, based on the following tests. Firstly, application of Harman's single factor method by constraining to one factor in exploratory factor analysis results in a factor that accounts for 36 percent of variance, which is not a majority. Insertion of a common method variable in the measurement model noted in Table 1 results in very slightly improved fit statistics and an insignificant difference in the model's chi-square at $\mathrm{p}<0.05$. Insertion of a marker latent variable into the measurement model which Table 1 lists indicates low common method variance.

\subsection{Measure development}

Scales used for measurement of the study's constructs appear in the appendix. The measures used for supplier commitment are those used by Morgan and Hunt (1994), but with changes to the context. In the context of the Morgan and Hunt study, the buyer's commitment to the seller is the relevant perspective, but the current study takes the seller's perspective. Some of the Morgan and Hunt indicators dropped out of the scale during purification in the first stage of 
model estimation (Anderson \& Gerbing, 1988) as noted below. Morgan and Hunt designed and tested their scales for commitment with reflective specification, as they are conceptualized as a set of responses that a respondent would make, as an outcome of their being committed.

The supplier satisfaction scale is that of Kumar, Stern, \& Achrol (1992), which is suitable for this study because it takes the seller's perspective. Their scale is, again, reflective because the design of the indicators shows the strength of response that a respondent would make to a set of statements depending on their level of satisfaction. The indicator "The relationship of my company with this customer has been an unhappy one” has a somewhat low standardized regression weight, at 0.53 , probably because it is reverse-scored. The scale retains this indicator to preserve content validity, to retain the full meaning of the Kumar et al. scale, and on the basis that its corrected item-total correlation is above 0.5 (Hair, Anderson, Tatham, \& Black, 1998) and that the composite reliability is sound at 0.82 .

The scale for the seller's preferred customer treatment construct is reflective because the study conceptualizes the construct as the propensity of the seller to allocate resources preferentially to more attractive customers and it is accordingly operationalized by asking respondents to compare the customer on which they report in the questionnaire with other customers. The indicators are therefore a selection of representative informational resources of the type that a seller would expect to allocate to its buyer in greater amounts if the relationship is such that it receives preferred customer treatment. The scale was developed for this study and its indicators were tested with managers and in a pilot study as noted above. One indicator, "Dollars your firm puts into the relationship” has a lower regression weight than others, but is left in the scale for content validity and on the basis that its corrected item-total correlation is above 0.5 (Hair et al., 1998), and its removal increases the scale’s reliability only by a little. 
The study conceptualizes the customer financial attractiveness construct as the supplier’s perspective of the likely performance of the subject relationship over the next three years. The study therefore specifies this construct's indicators as reflective and as representing a sample of the types of returns that a supplier would expect in greater amounts as the outcome of a customer relationship that performs well. The items derive from those of Baxter and Matear (2004), with one item added. A "size of their business" item dropped out of the scale. Although the "sales revenue” item does not perform as well as the other two in this scale, it remains in the scale for similar reasons to those noted above.

\subsection{Analysis}

The study analyzes survey data using SPSS and Amos software with correlations, confirmatory factor analysis, and structural equation modeling. The Anderson \& Gerbing (1988) two-step process in structural equation modeling software first assesses the characteristics of the measures in a measurement model, including discriminant and convergent validity after respecification and removal of under-performing measures as required. This step allows for valid conclusions from the next step, which is structural model estimation. Structural equation modeling analysis accounts better for error than most other analytical techniques such as regression, allows simultaneous modeling of multiple exogenous and endogenous constructs, which regression does not do, and assesses indirect paths easily as noted below. Variance-based modeling (partial least squares) software is a useful tool for some conditions, such as marked departure from normality or small sample size (Hair, Sarstedt, Ringle, \& Mena, 2012; Hair, 
Ringle, \& Sarstedt, 2011; Reinartz, Haenlein, \& Henseler, 2009). These conditions do not apply to this study, which uses Amos covariance-based software.

Prior to testing in Amos, the data was assessed for normality using the KolmogorovSmirnov test. All manifest variables had univariate skew less than 2 and kurtosis less than 7, meaning they were below the "moderate” level at which Curran et al. (1996) found data could give "significant problems" in maximum likelihood estimation of models in structural equation modeling. Hence the study took no remedial action for non-normality. For reference, skew and kurtosis of summated scales for the Figure 1 model constructs appear in Table 2 below.

The appendix shows the measures of constructs and the internal consistencies of scales after purification of items, all of which have composite reliability in excess of 0.7 (Fornell \& Larcker, 1981; Hair et al., 1998; Nunnally \& Bernstein, 1994). Purified items (Churchill, 1979) are redundant or are reverse-scored, the latter meaning they did not load well. Items load well on their intended constructs in exploratory factor analysis. Table 1 shows that the measurement model in the first row of numbers, which includes all four constructs and their purified items, has good fit statistics (Hair et al., 1998; Hu \& Bentler, 1999). The CMIN statistic has a significant pvalue, which is likely for a relatively large sample size, but the other fit statistics all indicate good fit of the model to the data. The construct measures all have convergent validity, as their regressions on the constructs they measure are all significant at $\mathrm{p}<0.001$ and their regression coefficients on the constructs they measure are substantial, and most are well in excess of 0.6. Further, average variance extracted (AVE) for each scale is well above 0.7 , so is in excess of the 0.5 minimum (Fornell \& Larcker, 1981). Bootstrapped Amos correlations between the model’s four constructs are in Table 2, with square root of average variance extracted (AVE) for each construct on the diagonal. The square roots of the AVEs are all greater than the correlations in 
rows and columns, indicating discriminant validity (Fornell \& Larcker, 1981). The fact that bootstrapped correlations plus or minus two standard errors do not approach anywhere near the value of 1 is also a rigorous indicator of discriminant validity (Anderson \& Gerbing, 1988). The scales therefore have sound psychometric properties. Inspection of the data analysis suggests that multicollinearity between constructs is not a problem (e.g. Grewal, Cote, \& Baumgartner, 2004). The highest correlation between constructs is 0.51 , reliability as assessed by composite reliability is reasonably high, sample size is fairly high, and discriminant validity is established.

Insert Table 1 about here

Insert Table 2 about here

The Figure 1 structural model has good fit statistics, as in the second row of numbers in Table 1. The standardized regression weights and p-values in Figure 1 show that all paths in the model are significant, supporting the relevant hypotheses, except for $\mathrm{H}_{4}$ from supplier satisfaction to preferred customer treatment. The paths through supplier commitment fully mediate the $\mathrm{H}_{4}$ path, as the non-significant $\mathrm{H}_{4}$ path and a statistically significant bootstrapped indirect path through $\mathrm{H}_{6}$ and $\mathrm{H}_{2}$ of weight 0.19 shows. The $\mathrm{H}_{2}$ path from supplier commitment to preferred customer treatment has a strong standardized regression weight 0.41 , significant at $\mathrm{p}<0.001$. The $\mathrm{H}_{3}, \mathrm{H}_{5}$ and $\mathrm{H}_{1}$ paths from customer financial attractiveness to supplier commitment, supplier satisfaction, and preferred customer treatment have standardized regression weights of 0.17 , 0.27, and 0.27 respectively. The $\mathrm{H}_{5}$ and $\mathrm{H}_{1}$ paths to supplier satisfaction and supplier's preferred customer treatment are significant at $\mathrm{p}<0.001$. The $\mathrm{H}_{3}$ path from customer financial 
attractiveness to supplier commitment has lesser significance at $\mathrm{p}<0.01$, reflecting the fact that the $\mathrm{H}_{5}$ and $\mathrm{H}_{6}$ paths partially mediate it. The $\mathrm{H}_{6}$ path is a strong one, at standardized regression weight 0.47 and $\mathrm{p}<0.001$. The squared multiple correlations for two key constructs, supplier commitment and preferred customer treatment, are 0.29 and 0.3 respectively. As a check on over-fitting, which is unlikely with an RMSEA of 0.04, the model was run with 200 randomly chosen cases rather than the full 314 cases. CMIN is non-significant, and the pattern of path coefficients is the same as when the estimation uses all 314 cases.

The testing for moderators inserted a multiplicative term in regressions with variables that were mean-centered before analysis. Measures of moderators are single-item, apart from that for trust, which comprises summated items from the Morgan \& Hunt (1994) scale. Two items dropped out from this scale, resulting in a congeneric measurement model with fit statistics as follows: CMIN 7.03; Df 5; p-value 0.22; CMIN/DF 1.41; RMSEA 0.04; TLI 0.99; GFI 0.99; SRMR 0.01; NFI 0.99. The regression analysis showed moderation in two cases. Trust moderates the $\mathrm{H}_{5}$ path from customer financial attractiveness to satisfaction, with interaction between customer financial attractiveness and trust shown by a significant increase in the $\mathrm{R}^{2}$ of satisfaction at $\mathrm{p}<0.05$. Employee numbers of the respondent (seller) firm moderates the same $\mathrm{H}_{5}$ path, with interaction between customer financial attractiveness and trust shown by a significant increase in the $\mathrm{R}^{2}$ of satisfaction at $\mathrm{p}<0.01$.

\section{Discussion}

\subsection{Theoretical implications}

The study provides information that will help firms understand how they are able to encourage the allocation of resources to them by their suppliers. This understanding is important 
because it will aid them to formulate strategies to gain the resources they need from their suppliers. The study achieves its aims by supporting the model as in Fig. 1. The study's model proposes that a seller's perception of the financial attractiveness of its relationship with a customer has a clear influence on its levels of preferred customer treatment by way of allocation of resources to its customer. The supplier's satisfaction with and commitment to the relationship with the customer mediate this influence. Their squared multiple correlations show that the two key constructs, supplier commitment and preferred customer treatment , are respectively $28.7 \%$ and 29.5\% explained by the customer financial attractiveness. This is a strong level of explanation, given the other possible effects on these two constructs. For example, other factors that could influence preferred customer treatment include market and competitive conditions, economic conditions and competing projects such as development of other new products. Supplier perceptions of customer relationship financial performance are therefore a strong driver of preferred customer treatment, through supplier commitment.

Demonstration of the effect of the supplier's perception of relationship performance as a driver of supplier satisfaction and supplier commitment and as an encouragement to suppliers to invest resources in the relationship is an important contribution. Although perhaps intuitively clear, this effect is not too clear in the literature and its illustration in this study is a timely reminder for managers and researchers of its importance.

The 0.41 coefficient for the $\mathrm{H}_{2}$ path also shows that supplier commitment has a strong effect on supplier's preferred customer treatment. Supplier commitment fully mediates the model's $\mathrm{H}_{4}$ path from supplier satisfaction and partially mediates the $\mathrm{H}_{1}$ direct path from customer financial attractiveness to preferred customer treatment. The effect of customer financial attractiveness therefore drives preferred customer treatment powerfully through 
supplier commitment. Supplier commitment, a construct that is more widely studied in disciplines other than marketing, is thus an important construct for consideration by marketing managers and researchers. Marketing managers in both buying and selling firms are closely involved in the management of the transfer of resources between the buyer and the seller and in the creation of new resources in buyer-seller relationships, and good outcomes require the commitment of both firms.

From a research point of view, the study makes several theoretical contributions, listed as follows. First, the study adds strong evidence to the marketing literature that customer attractiveness is important, following the lead of the logistics and purchasing literature, which is noted in this paper's introduction. Second, the study is the first to quantitatively verify, from suppliers' perspective, that indeed suppliers differentiate the service they offer to customers on the basis of customer attractiveness and it does so by explicitly asking respondents to compare the customer on which they report in the questionnaire with others. This operationalization fully fits with the preferred customer concept, which is defined as the differential input of prime resources by the supplier. Third, the results show that supplier commitment to customers and preferred customer treatment in terms of resource allocation by the supplier are two distinct concepts. Fourth, the study shows the important role that supplier satisfaction plays in the supplier's preferential treatment of more attractive customers and that it does so through supplier commitment rather than directly. Fifth, it adds empirical evidence to the several literature streams, including the S-DL and the resource-based view, that espouse the importance of resource exchange across buyer-seller relationships for the development of new products and processes and it shows that partner performance is an important determinant of the level of this resource exchange. Sixth, the study provides quantitatively determined evidence to support the 
work of the IMP group on the importance of resource exchange as a function of buyer-seller relationships.

\subsection{Managerial implications}

The study's findings provide useful specific points for managerial action. The findings show how important it is for managers to attend to relationship management in order to gain preferential investments of resources in the relationship from their suppliers. If they want suppliers to allocate resources to them, they need to manage suppliers' perceptions. They need to make clear to the supplier that the relationship will perform well financially, and they need to manage supplier satisfaction with the relationship and supplier commitment to the relationship. Managers need to put resources into their relationships with their suppliers if they want to get resources from the suppliers: “you’ve got to spend a dollar to make a dollar”.

The importance of the facilitating factors, supplier satisfaction and supplier commitment, is clearly shown in the strong paths in the Figure 1 model. The indicators for the study's constructs give examples of exactly the kinds of information that the buyer needs to give to its supplier and the kinds of action the buyer needs to take. For example, the buyer needs to give projections of the level of profitability the seller can expect, as an indication of future performance and to cultivate a good working relationship with the seller. Although another facilitating factor, trust, is modeled only as a moderator, is specified only in its affective aspect, and has only $\mathrm{p}<0.05$ significance, its effect does contribute to satisfaction levels, which is useful information for managers. The positive moderation effect of firm size on the path from customer financial attractiveness to satisfaction suggests that customers should work on the perceptions of their financial attractiveness particularly with larger supplying firms. 
There are many potential ways in which the buyer can take action to improve the relationship and help the seller's understanding that this is a good relationship and is worthy of the seller's investment. Regular meetings and creative workshops between buyer and supplier require inputs of time and other resources by the buyer as well as the supplier, but can bring valuable insights and new solutions to problems. The customer can keep the supplier informed about its position in its markets and thereby aid the supplier's perception of its financial attractiveness and the future profitability of the relationship. The customer can find how it could be more helpful to the supplier in facilitating the relationship by changes in relationship-relevant processes such as documentation or by changes in packaging that help the supplier. In a sound relationship, the buyer can give the supplier access to more of its internal information: more information tends to remover uncertainty, hence making a partner more comfortable. In such an atmosphere, and opportunism concerns aside, clear indications of a customer's benevolence towards a supplier and an open-door policy can aid the relationship and result in a more satisfied supplier. In the case of a potential purchase and supply agreement, supply of information can aid the parties to reach an agreement to do business.

Timely supply of information in both directions in a buyer-seller relationship aids both parties in terms of their feeling of comfort and their ability to plan their actions. Such information supply requires well-established personal relations between people on each side of the relationship. This, in turn, requires stability of personnel and this stability extends beyond the sales and purchasing staff of the seller and the buyer: relationships need to form between their technical, logistics, and IT personnel, for example. Tacit information (Nonaka, 1991) is often the kind of intangible resource that builds greatest mutual long-term competitive advantage for both 
parties across a buyer-seller relationship (Morgan \& Hunt, 1999). Effective exchange of this type of information requires the kind of understanding built in the long term between people.

\subsection{Limitations and future research}

The study has limitations in terms of its cross-sectional view and the fact that it considers only one perspective in the dyad. . There is always the possibility of specification errror in a study such as the one this paper describes, where the costructs are abstract. The assessment of non-response bias using the Armstrong \& Overton (1977) method has limited efficacy, so such bias is still a possibility. This non-response bias limitation can to some extent be overcome by employing techniques such as sampling non-respondents (Wagner \& Kemmerling, 2010), although those techniques also have issues, for example loss of anonymity of respondents and more likelihood of receiving socially desirable responses rather than honest responses.

A possible perspective for future research is a more detailed analysis of how the study's constructs affect the buyer's preferred customer treatment. Manufacturers were the context for this study, so it will be a worthwhile extension to investigate the study's issues in service contexts. The study contributes to theory both in its reverse perspective view of the dyad and its consideration of the outcomes of relationship performance, rather than considering the antecedents of performance. In doing so, it provides a good base for further extension of theory and practice in future research. Extension of the model to the buyer's perspective of how to gain preferred treatment and ensure allocation of resources by the seller is an opportunity. Another extension will be to investigate how the constructs in the Figure 1 model then affect outcomes such as new product development in terms of style, type and success of these developments. This 
study uses the more affective Morgan \& Hunt (1994) conceptualization of trust as a moderator so it will be interesting to assess the distinct calculative and affective aspects of trust (Johnson \& Grayson, 2005) in future research. Exploratory research might show how these fit in the broader nomological net of this study more clearly. This is well worth pursuing, given the fact that trust is so often a mediator in buyer-seller relationships (e.g. Huntley, 2006). Assessment of the two potentially distinct affective and calculative aspects of supplier commitment (Geyskens, Steenkamp, Scheer, \& Kumar, 1996) will also be interesting. 
APPENDIX: SCALE ITEMS

Scales (anchor points) and items

Preferred customer treatment

Please consider again your firm's relationship with your chosen customer over the next 3 years. How high do you expect your firm's level of input of the

following resources to be into the relationship, compared with your other customers?

(Very much lower - Very much higher)

Dollars your firm puts into the relationship

Time input of your personnel

Your intangible inputs, such as your knowledge, skills, ingenuity, relationships

Physical items such as equipment you put into the relationship

Customer financial attractiveness

Thinking now about the next 3 years, how do you expect your chosen customer's performance to rate? Please rate on the scale at the right according to the following criteria, as compared with your other customers.

(Very much lower - Very much higher)

The sales revenue they provide to your company.

The profitability of your organization's business with this customer.

Return on investment of your organization's business with this customer.

The size of their business with you relative to your total business

\section{Supplier commitment}

The relationship that your firm has with the chosen customer:

(Strongly disagree - Strongly agree)

Is something you are very committed to

Is something your firm intends to maintain indefinitely Is something your firm really cares about

Deserves your firm's maximum effort to maintain

Is very important to your firm.

Is of very little significance to your firm (reverse scored)

Is very much like being family

\section{Supplier satisfaction}

To what extent do the following statements describe your relationship with your chosen customer? (Not at all - Very much so)

The relationship of my company with this customer has been an unhappy one.

My company is very pleased with its working relationship with this customer.

Generally, my company is very satisfied with its overall relationship with this customer.

\section{Mean Standard deviation

$\begin{array}{cc}\text { Standardized } & \text { Composite } \\ \text { regression } \\ \text { weight }\end{array} \quad \begin{gathered}\text { reliability } \\ \end{gathered}$

4.31

1.06

0.56

5.03

1.05

0.90

$5.24 \quad 1.06$

0.78

$4.00 \quad 1.33$

0.84

$\begin{array}{lll}5.01 & 1.02 & 0.56 \\ 4.68 & 1.02 & 0.85 \\ & & \\ 4.83 & 1.06 & 0.97\end{array}$

$4.48 \quad 1.14$

0.87

6.24

6.28

6.03

6.15

6.24

6.38

0.92

0.98

1.05

1.05

1.02

$4.69 \quad 1.54$

0.82

0.70

0.84

0.80

$\begin{array}{lll}6.14 & 1.14 & 0.53\end{array}$

$\begin{array}{lll}5.73 & 1.18 & 0.92\end{array}$

$\begin{array}{lll}5.62 & 1.20 & 0.90\end{array}$ 
Trust moderator

Trust

In your relationship, your chosen customer:

(Strongly disagree - strongly agree)

Cannot be trusted at times (reverse scored)

$\begin{array}{lll}5.15 & 1.71 & 0.71\end{array}$

Is perfectly honest and truthful

$4.98 \quad 1.60$

0.81

Can be trusted completely

$4.83 \quad 1.61$

0.93

Can be counted on to do what is right

$5.03 \quad 1.45$

0.90

Is always faithful

4.55

1.56

0.82

Firm size moderators

Customer size moderator

- by employee numbers

$\underline{\text { Seller size moderator }}$

- by employee numbers

Relationship characteristics moderators

How much do you agree with the following statements

about your firm's relationship with the chosen

customer, as compared with other customers?

(I do not agree at all - I fully agree)

$\underline{\text { Social bonds }}$

We have strong social bonds with people in the

$4.53 \quad 1.62$

customer organization

Shared goals

$\begin{array}{ll}4.62 & 1.47\end{array}$

Our firm shares a lot of goals with this customer

Supplier investments

We make a lot of specific investments in this

relationship

Customer investments

$4.29 \quad 1.55$

The customer makes a lot of specific investments in

this relationship

Service versus product moderator

Please circle the number that best shows the mix of products and/or services your firm offers:

Only products/An equal product/service mix/

Only services

- on a 1 to 7 scale

Notes: 1. Numbers in the column headed "Standardized regression weight" are path weights between each measure and the construct it reflects in the measurement model whose fit statistics are in Table 1.

2. Standardized regression weights in this appendix are all significant at $\mathrm{p}<0.001$.

3. Italicized items were deleted from measurement model during purification 


\section{References}

Abdul-Muhmin, A. G. (2005). Instrumental and interpersonal determinants of relationship satisfaction and commitment in industrial markets. Journal of Business Research, 58(5), 619-628.

Anderson, J. C., \& Gerbing, D. W. (1988). Structural Equation Modeling in Practice: a Review and Recommended Two-Step Approach. Psychological Bulletin, 103(3), 411-423.

Anderson, J. C., Håkansson, H., \& Johanson, J. (1994). Dyadic business relationships within a business network context. Journal of Marketing, 58(4), 1.

Anderson, J. C., \& Narus, J. A. (1990). A Model of Distributor Firm and Manufacturer Firm Working Partnerships. Journal of Marketing, 54(January), 42-58.

Armstrong, J. S., \& Overton, T. S. (1977). Estimating Nonresponse Bias in Mail Surveys. Journal of Marketing Research, XIV(August), 396-402.

Ballantyne, D., \& Varey, R. J. (2006). Creating value-in-use through marketing interaction: the exchange logic of relating, communicating and knowing. Marketing Theory, 6(3), 335348.

Baraldi, E., \& Waluszewski, A. (2007). Conscious use of others' interface knowledge. In H. Håkansson \& A. Waluszewski (Eds.), Knowledge and Innovation in Business and Industry: The importance of using others (pp. 79-108). London: Routledge.

Baxter, R., \& Matear, S. (2004). Measuring Intangible Value in Business to Business BuyerSeller Relationships: An Intellectual Capital Perspective. Industrial Marketing Management, 33(6), 491-500. 
Bennett, R., \& Gabriel, H. (2001). Reputation, trust and supplier commitment: the case of shipping company/seaport relations. Journal of Business \& Industrial Marketing, 16(6), 424-438.

Berry, L. L. (1995). Relationship Marketing of Services--Growing Interest, Emerging Perspectives. Journal of the Academy of Marketing Science, 23(4), 236-245.

Churchill, G. A., Jr. (1979). A Paradigm for Developing Better Measures of Marketing Constructs. Journal of Marketing Research, XVI (February 1979), 64-73.

Cohen, J. (1988). Statistical power analysis for the behavioral sciences.(2 ed.). Hillsdale, NJ: Lawrence Erlbaum Associates, Inc.

Curran, P. J., West, S. G., \& Finch, J. F. (1996). The Robustness of Test Statistics to Nonnormality and Specification Error in Confirmatory Factor Analysis. Psychological Methods, 1(1), 16-29.

Fang, E., Palmatier, R. W., \& Evans, K. R. (2008). Influence of customer participation on creating and sharing of new product value. Journal of the Academy of Marketing Science, 36(3), 322-336.

Dillman, D. A. (1978). Mail and Telephone Surveys: The Total Design Method. New York: Wiley.

Dyer, J. H. (1996). Specialized Supplier Networks as a Source of Competitive Advantage: Evidence from the Auto Industry. Strategic Management Journal, 17, 271-291.

Essig, M., \& Amann, M. (2009). Supplier satisfaction: Conceptual basics and explorative findings. Journal of Purchasing and Supply Management, 15(2), 103-113.

Ford, D. (1980). The Development of Buyer-Seller Relationships in Industrial Markets. European Journal of Marketing, 14(5/6), 339 - 353. 
Fornell, C., \& Larcker, D. F. (1981). Structural Equation Models with Unobservable Variables and Measurement Error: Algebra and Statistics. Journal of Marketing Research, 18(3), 382.

Gadde, L.-E., Huemer, L., \& Håkansson, H. (2003). Strategizing in industrial networks. Industrial Marketing Management, 32(5), 357-364.

Geyskens, I., Steenkamp, J.-B. E. M., Scheer, L. K., \& Kumar, N. (1996). The effects of trust and interdependence on relationship commitment: A trans-Atlantic study. International Journal of Research in Marketing, 13(4), 303-317.

Geyskens, I., Steenkamp, J. B., \& Kumar, N. (1999). A Meta-Analysis of Satisfaction in Marketing Channel Relationships. Journal of Marketing Research(May), 223-238.

Ghijsen, P. W. T., Semeijn, J., \& Ernstson, S. (2010). Supplier satisfaction and commitment: The role of influence strategies and supplier development. Journal of Purchasing and Supply Management, 16(1), 17-26.

Grewal, R., Cote, J. A., \& Baumgartner, H. (2004). Multicollinearity and Measurement Error in Structural Equation Models: Implications for Theory Testing. Marketing Science, 23(4), 519-529.

Gustafsson, A., Johnson, M. D., \& Roos, I. (2005). The Effects of Customer Satisfaction, Relationship Commitment Dimensions, and Triggers on Customer Retention. Journal of Marketing, 69(4), 210-218.

Hair, J. F., Jr., Anderson, R. E., Tatham, R., L., \& Black, W. C. (1998). Multivariate Data Analysis (5 ed.). Upper Saddle River: Prentice-Hall. 
Hair, J., Sarstedt, M., Ringle, C., \& Mena, J. (2012). An assessment of the use of partial least squares structural equation modeling in marketing research. Journal of the Academy of Marketing Science, 40(3), 414-433.

Hair, J. F., Ringle, C. M., \& Sarstedt, M. (2011). PLS-SEM: Indeed a Silver Bullet. Journal of Marketing Theory \& Practice, 19(2), 139-152.

Håkansson, H. (Ed.). (1982). International Marketing and Purchasing of Industrial Goods: An Interaction Approach. Chichester: John Wiley and Sons.

Hakansson, H., \& Snehota, I. (1982). Developing Relationships in Business Markets. London: Routledge.

Håkansson, H., \& Snehota, I. (Eds.). (1995). Developing Relationships in Business Networks. London: Routledge.

Handfield, R. B., Krause, D. R., Scannell, T. V., \& Monczka, R. M. (2000). Avoid the Pitfalls in Supplier Development. Sloan Management Review, 41(2), 37-49.

Hennig-Thurau, T., Gwinner, K. P., \& Gremler, D. D. (2002). Understanding relationship marketing outcomes: An integration of relational benefits and relationship quality. Journal of Service Research, 4(3), 230-247.

Hu, L.-t., \& Bentler, P. M. (1999). Cutoff Criteria for Fit Indices in Covariance Structure Analysis: Conventional Criteria Versus New Alternatives. Structural Equation Modelling, 6(1), 1-55.

Huntley, J. K. (2006). Conceptualization and measurement of relationship quality: Linking relationship quality to actual sales and recommendation intention. Industrial Marketing Management, 35(6), 703-714. 
Jap, S. D., \& Ganesan, S. (2000). Control Mechanisms and the Relationship Life Cycle: Implications for Safeguarding Specific Investments and Developing Commitment. Journal of Marketing Research, 37(2), 227-245.

Joshi, A. W. (2009). Continuous Supplier Performance Improvement: Effects of Collaborative Communication and Control. Journal of Marketing, 73(1), 133-150.

Krause, D. R. (1999). The antecedents of buying firms' efforts to improve suppliers. Journal of Operations Management, 17(2), 205-224.

Kumar, N., Stern, L. W., \& Achrol, R. S. (1992). Assessing Reseller Performance From the Perspective of the Supplier. Journal of Marketing Research, XXIX(May), 238-253.

Morgan, R. M., \& Hunt, S. D. (1994). The Commitment-Trust Theory of Relationship Marketing. Journal of Marketing, 58(July), 20-38.

Morgan, R. M., \& Hunt, S. D. (1999). Relationship-Based Competitive Advantage: The Role of Relationship Marketing in Marketing Strategy. Journal of Business Research, 46, 281290.

Nonaka, I. (1991). The Knowledge-Creating Company. Harvard Business Review, 69(November-December), 96-104.

Nunnally, J. C., \& Bernstein, I. H. (1994). Psychometric Theory (3 ed.). New York: McGrawHill.

O'Toole, T., \& Donaldson, B. (2000). Relationship Governance Structures and Performance. Journal of Marketing Management, 16(4), 327-341.

O'Toole, T., \& Donaldson, B. (2002). Relationship Performance Dimensions of Buyer-Supplier Exchanges. European Journal of Purchasing and Supply Management, 8(4), 197-207. 
Palmatier, R., Dant, R., Grewal, D., \& Evans, K. (2006). Factors Influencing the Effectiveness of Relationship Marketing: A Meta-Analysis. Journal of Marketing, 70(4), 136-153.

Palmatier, R. W., Dant, R. P., \& Grewal, D. (2007). A Comparative Longitudinal Analysis of Theoretical Perspectives of Interorganizational Relationship Performance. Journal of Marketing, 71(4), 172-194.

Palmatier, R. W. (2008). Interfirm Relational Drivers of Customer Value. Journal of Marketing, 72(4), 76-89.

Podsakoff, P. M., MacKenzie, S. B., Lee, J.-Y., \& Podsakoff, N. P. (2003). Common Method Biases in Behavioral Research: A Critical Review of the Literature and Recommended Remedies. Journal of Applied Psychology, 88(5), 879.

Payne, A. F., Storbacka, K., \& Frow, P. (2008). Managing the co-creation of value. Journal of the Academy of Marketing Science, 36(1), 83-96.

Penrose, E. T. (1959). The Theory of the Growth of the Firm. Oxford: Basil Blackwell.

Petersen, K. J., Handfield, R. B., \& Ragatz, G. L. (2005). Supplier integration into new product development: coordinating product, process and supply chain design. Journal of Operations Management, 23(3/4), 371-388.

Prahinski, C., \& Benton, W. C. (2004). Supplier evaluations: communication strategies to improve supplier performance. Journal of Operations Management, 22(1), 39-62.

Provan, K. G., \& Gassenheimer, J. B. (1994). Supplier Commitment in Relational Contract Exchanges with Buyers: A Study of Interorganizational Dependence and Exercised Power. Journal of Management Studies, 31(1), 55-68. 
Ragatz, G. L., Handfield, R. B., \& Petersen, K. J. (2002). Benefits associated with supplier integration into new product development under conditions of technology uncertainty. Journal of Business Research, 55(5), 389-400.

Reinartz, W., Haenlein, M., \& Henseler, J. (2009). An empirical comparison of the efficacy of covariance-based and variance-based SEM. International Journal of Research in Marketing, 26(4), 332-344.

Ritter, T., \& Walter, A. (2012). More is not always better: The impact of relationship functions on customer-perceived relationship value. Industrial Marketing Management, 41(1), 136144.

Schiele, H. (2010). Early supplier integration: the dual role of purchasing in new product development. R\&D Management, 40(2), 138-153.

Schiele, H. (2012). Accessing Supplier Innovation By Being Their Preferred Customer. Research Technology Management, 55(1), 44-50.

Schiele, H., \& Krummaker, S. (2011). Consortium benchmarking: Collaborative academicpractitioner case study research. Journal of Business Research, 64(10), 1137-1145.

Schiele, H., Veldman, J., \& Hüttinger, L. (2011). Supplier Innovativeness and Supplier Pricing: The Role of Preferred Customer Status. International Journal of Innovation Management, 15(1), 1-27.

Suh, T., \& Kwon, I.-W. G. (2006). Matter over mind: When specific asset investment affects calculative trust in supply chain partnership. Industrial Marketing Management, 35(2), $191-201$. 
Ulaga, W., \& Eggert, A. (2006). Relationship value and relationship quality: Broadening the nomological network of business-to-business relationships. European Journal of Marketing, 40(3/4), 311-327.

Van Echtelt, F. E. A., Wynstra, F., Van Weele, A. J., \& Duysters, G. (2008). Managing Supplier Involvement in New Product Development: A Multiple-Case Study. Journal of Product Innovation Management, 25(2), 180-201.

Vargo, S. L., \& Lusch, R. F. (2004). Evolving to a New Dominant Logic for Marketing. Journal of Marketing, 68(1), 1-17.

Vargo, S. L. (2009). Toward a transcending conceptualization of relationship: a servicedominant logic perspective. Journal of Business \& Industrial Marketing, 24(5), 373-379.

Wagner, S. M., \& Kemmerling, R. (2010). Handling Nonresponse in Logistics Research. Journal of Business Logistics, 31(2), 357-381.

Walter, A. (2003). Relationship-specific factors influencing supplier involvement in customer new product development. Journal of Business Research, 56(9), 721-733.

Walter, A., Ritter, T., \& Gemünden, H. G. (2001). Value Creation in Buyer-Seller Relationships: Theoretical Considerations and Empirical Results from a Supplier's Perspective. Industrial Marketing Management, 30(4), 365-377.

Wiley, J., Wilkinson, I., \& Young, L. (2005). Evaluating a Model of Industrial Relationship Performance: A Comparison of European and Chinese results using the IMP Data Base. Australasian Marketing Journal, 13(2), 49-49-60.

Williamson, O. E. (1993). Calculativeness, Trust, and Economic Organization. Journal of Law and Economics, 36(1), 453-486. 
Wilson, D. T. (1995). An Integrated Model of Buyer-Seller Relationships. Journal of the Academy of Marketing Science, 23(4), 335-345.

Wong, A. (2000). Integrating supplier satisfaction with customer satisfaction. Total Quality Management, 11(4-6), 427-432.

Wong, A. (2002). Sustaining company performance through partnering with suppliers. International Journal of Quality \& Reliability Management, 19(5), 567-580. 


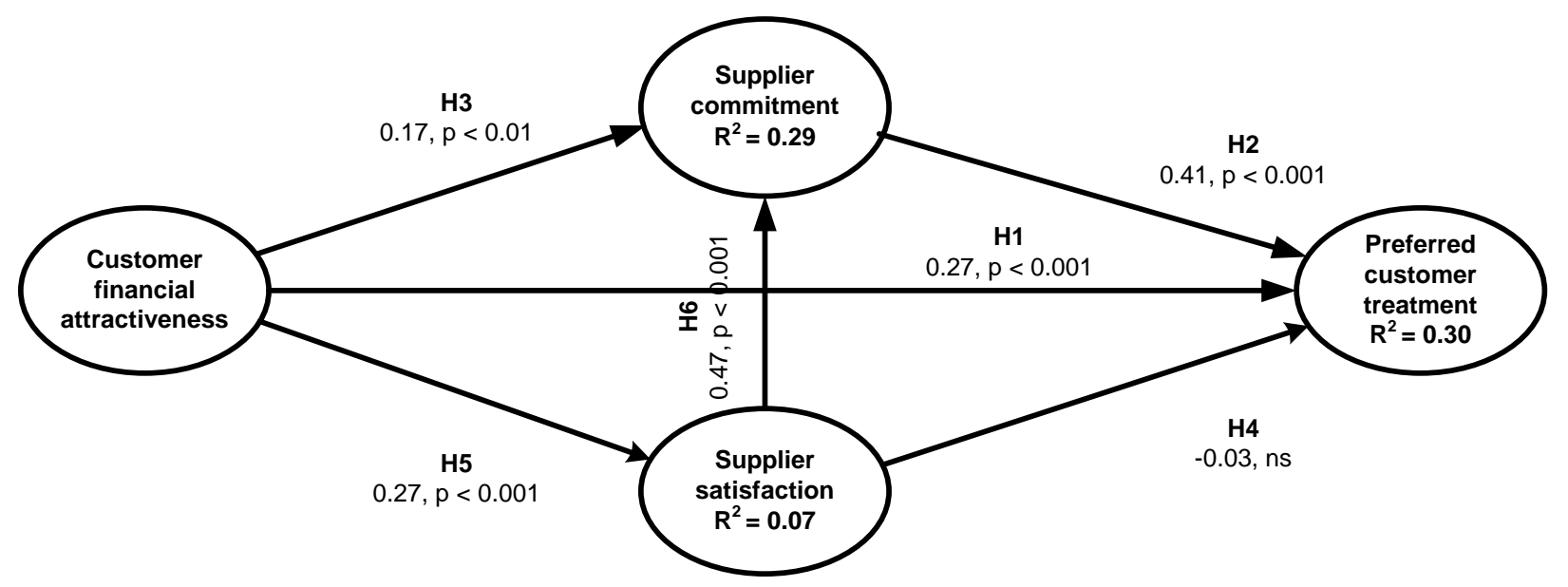

Notes: 1 . Numbers on paths are standardized regression coefficient, $\mathrm{p}$ - value; ns means not significant

2. $\mathrm{R}^{2}$ numbers are squared multiple correlations of constructs

3. Cohen's $f^{2}$ numbers for effect size of paths to preferred customer treatment from supplier satisfaction, customer financial attractiveness and supplier commitment are respectively: 0.0 (negligible); 0.08 (weak); 0.16 (moderate). 4. Cohen's $f^{2}$ numbers for effect size of paths to supplier commitment from customer financial attractiveness and supplier satisfaction are respectively: 0.03 (weak); 0.27 (moderate) (Cohen, 1988).

Figure 1: Supplier commitment and preferred customer treatment as relationship outcomes 
Table 1: Model fit statistics

$\begin{array}{lcccccccc} & \text { CMIN } & \text { Df } & \text { p-value } & \text { CMIN/Df } & \text { RMSEA } & \text { TLI } & \text { GFI } & \text { SRMR } \\ \text { Measurement model } & 93.37 & 59 & 0.04 & 1.58 & 0.04 & 0.98 & 0.96 & 0.05 \\ \text { Structural model as in Figure 1 } & 93.37 & 59 & 0.00 & 1.58 & 0.04 & 0.98 & 0.96 & 0.05\end{array}$

Note: p-value is for the CMIN (Chi square) statistic 
Table 2: Construct skewness, kurtosis, correlations and discriminant validity information

$\begin{array}{llcccccc} & \text { Construct } & \text { Skewness } & \text { Kurtosis } & \mathbf{1} & \mathbf{2} & \mathbf{3} & \mathbf{4} \\ \mathbf{1} & \text { Customer financial attractiveness } & -0.45 & 0.78 & 0.89 & & & \\ \mathbf{2} & \text { Supplier satisfaction } & -0.97 & 0.50 & 0.27 & 0.89 & & \\ \mathbf{3} & \text { Supplier commitment } & -1.61 & 4.19 & 0.29 & 0.51 & 0.89 & \\ \mathbf{4} & \text { Preferred customer treatment } & -0.49 & 0.71 & 0.38 & 0.26 & 0.48 & 0.86\end{array}$

Notes: 1 . Skewness and kurtosis are for summated scales

2. Values under diagonal are bootstrapped correlations

3. Values on diagonal are square roots of average variance extracted 